\title{
THE EFFECT OF ORGANIZATIONAL CULTURE, MOTIVATION, AND SELF-LEADERSHIP ON STUDENT PERFORMANCE IN START-UPS
}

\author{
Amalia Putri Ghassani*), Wirawan ED Radianto*)1, and Stanislaus Mastan*) \\ *) Ciputra University Surabaya \\ Citraland CBD Boulevard, Surabaya 60219, Indonesia
}

\begin{abstract}
The development of entrepreneurial education designed currently is developing rapidly. One of the goals of this education is to produce new start-ups. Therefore, factors that impact the performance of start-ups by university students are important to be studied further. This study aimed to determine the impact of organizational culture, motivation, and self-leadership on the performance of students of the Accountancy Study Program in a private university in Surabaya, which has entrepreneurship as part of their curriculum. This private university is a university with the vision of creating entrepreneurs. Therefore, the learning method provided is project-based learning. All students have to undergo entrepreneurship learning, and thus, they are required to create start-ups according to their field of study and according to their respective study program. The success of the students' start-ups will undoubtedly require excellent performance in achieving the set target. This study was conducted using a quantitative method and analyzed using multiple regression analysis. The result of this study suggested that organizational culture and self-leadership had an impact on students' performance in start-ups. However, motivation had no impact on students' performance in start-ups.
\end{abstract}

Keywords: entrepreneurial education, organizational culture, performance, motivation, selfleadership

Abstrak: Perkembangan pendidikan kewirausahaan yang dirancang saat ini sedang berkembang pesat. Salah satu tujuan dari pendidikan ini adalah untuk menghasilkan start-up. Oleh karena itu, faktor-faktor yang memengaruhi kinerja start-up oleh mahasiswa penting untuk dipelajari lebih lanjut. Tujuan dari penelitian ini adalah untuk mengetahui dampak budaya organisasi, motivasi, dan self-leadership terhadap kinerja siswa Program Studi Akuntansi, yang memiliki kewirausahaan sebagai bagian dari kurikulum mereka di salah satu universitas swasta di Surabaya. Universitas swasta ini adalah universitas dengan visi menciptakan pengusaha. Oleh karena itu, metode pembelajaran yang disediakan adalah pembelajaran berbasis proyek. Semua siswa harus menjalani pembelajaran kewirausahaan dan dengan demikian, siswa diwajibkan untuk membuat start-up sesuai dengan bidang studi mereka dan sesuai dengan program studi masing-masing. Keberhasilan start-up siswa tentu akan membutuhkan kinerja yang baik dalam mencapai target yang ditetapkan. Penelitian ini dilakukan dengan menggunakan metode kuantitatif dan dianalisis menggunakan analisis regresi berganda. Hasil penelitian menunjukkan bahwa budaya organisasi dan kepemimpinandiri berdampak pada kinerja siswa dalam start-up. Namun, motivasi tidak berdampak pada kinerja siswa di start-up.

Kata kunci: pendidikan kewirausahaan, budaya organisasi, kinerja, motivasi, self-leadership

${ }^{1}$ Corresponding author:

Email: wirawan@ciputra.ac.id 


\section{INTRODUCTION}

The development of entrepreneurship occurs rapidly in Indonesia. It can be seen from the high number of start-ups emerging in Indonesia. A sufficient number of universities that develop their students' entrepreneurship support this condition. One of the universities focusing on entrepreneurship is Ciputra University. All students of Ciputra University must have their start-ups. Due to the importance of this study, the university has permitted the author to conduct this study.

Students, as the driving force of start-ups, can yield certain advantages and success from their start-ups (Jatilaksono and Indartono, 2016). The success of the student's start-up will undoubtedly require excellent performance in achieving the set target. Performance is work accomplishments in the form of quality or quantity achieved by the students in completing their assigned tasks and responsibilities (Akbar, 2015). Students' performance will certainly be a determining factor in the growth of the start-up that they create since it will influence the student's contribution to achieving targets.

Several challenges that may occur in start-ups are the division of the business due to various factors, students' performance in conducting business, students' motivation in starting and growing the business, organizational culture, and self-leadership. Lack of motivation in conducting business can affect the performance of business members in conducting their tasks due to lack of encouragement to achieve business goals (Nisyak, 2016), Raf et al. (2014), and Rahmawaty (2014) stated that factors that affect performance include organizational culture, motivation, and selfleadership. Organizational culture is a manifestation of assumptions that are explicitly owned and accepted by a group and determines how the group thinks and behaves towards a diverse environment (Jatilaksono and Indartono, 2016). Organizational culture becomes a factor in the performance of the business because a strong culture can dictate the behavior of the business members and influence members to work together in a synergistic manner (Merchant and Stede, 2016). Targets that have been set can motivate students to improve their performance in running the start-up. Therefore, motivation can become one of the factors that impact performance (Merchant and Stede, 2016). Self-leadership is an essential aspect since business members can influence themselves to exert more effort to improve their work (Priyantono, 2017). Self-leadership can also enhance members' performance in start-ups since it can build individuals' capability to motivate themselves and to set achievement strategies (Masruroh and Sasriyah, 2015). The previous explanations suggest that studies on organizational culture, motivation, and self-leadership on performance have been conducted previously but have not been conducted using the context of designed entrepreneurial education.

Putra (2015) found that organizational commitment, organizational culture, leadership, and physical work environment had an impact on performance. Rachmawaty and Rohmah (2014) found that competency and self-leadership had a significant impact on business performance. Nazir and Zamir (2015) discovered a positive relationship between employees' performance and organizational culture and showed that there was no significant difference in employees' feedback across genders on organizational culture and employee performance. The study conducted by Omollo (2015) found that work motivation affects employee performance significantly.

The aim of this study was to determine the impact of organizational culture, motivation, and self-leadership on students' performance in start-ups. This study was conducted using a quantitative approach to investigate the role of organizational culture, motivation, and self-leadership on the performance of students of the Accountancy Study Program in start-ups.

\section{METHODS}

This study was conducted on Department of Accounting in Ciputra University. This study was conducted using primary data collected through questionnaire with survey methodology (Sugiyono, 2015). Questionnaires were sent to all students with the help of enumerator that met potential respondents in person. Data collection method used is through distribution of questionnaire using purposive sampling method. The criteria are accountancy study program students with businesses and said business need to already be operating for at least 2 years. In total there were 100 questionnaires distributed. There were 54 successfully collected and completely filled, which means the return rate is 54 percent. 
Summary of the operational definitions of the variables in the study and its indicators is presented in Table 1. Each indicator presented in Table 1 is measured in Likert scale, with option 1 as Strongly Disagree and so forth up until five for the option of Strongly Agree. The researcher conducted Multiple Regression Analysis on the data collected in order to examine the effect of the independent variables on the dependent variable (Widarjono, 2015).

From the research model (Figure 1) it showed that the variables of organizational culture, motivation, and self-leadership affect performance. In accordance with the analysis tools used, this study tested the overall model using the F-test. After passing the test, T-test will be conducted to test the effect of each variable. Finally, after the data analysis is completed, it will be continued with discussion and conclusions.

\section{Hypothesis}

Organizational culture could influence an individual's behavior in running a start-up (Rahmi, 2014). Therefore, the application of organizational culture in business could affect employees' performance (Hasan, 2016). Thus, the first hypothesis was as follows:
H1: Organizational culture had an impact on students' performance in start-ups.

Motivation will push individuals such that business members would exert their utmost effort to work optimally (Santoso, 2017). Motivation had an impact on an individual's performance in achieving startups' goals (Vionita et al. 2017). Therefore, the second hypothesis was as follows:

H2: Motivation had an impact on students' performance in start-ups.

Self-leadership affected an individual's performance that played an essential role in improving business performance (Furtner et al. 2015). Therefore, the third hypothesis was as follows:

H3: Self-leadership had an impact on students' performance in start-ups.

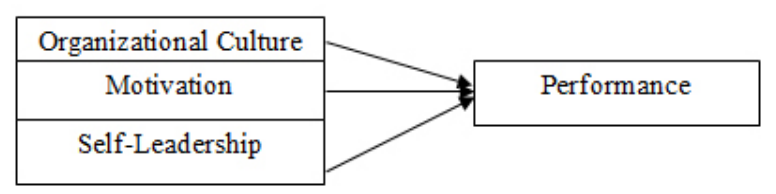

Figure 1. The research model

Table 1. t-test on start-up performance

\begin{tabular}{llc}
\hline \multicolumn{1}{c}{ Variable } & Indicator & \multicolumn{1}{c}{ Source } \\
\hline Organizational & Innovative in calculating risk & Jatilaksono and Indartono (2016) \\
& Attention to every problem & \\
& Oriented towards the results to be achieved & \\
& Oriented to the interests of all members & \\
& Aggressiveness & \\
& Maintaining work stability & Larasati and Gilang (2014) \\
Motivation & Need for Achievement & \\
& Affiliate Needs & Furtner et al. (2015) \\
Self-Leadership & Need for Power & \\
& Self-goal setting & \\
& Self-reward & \\
& Self-punishment & \\
& Self-observation & \\
& Self-cueing & Nisyak (2016) \\
Performance & The level of quantity and quality of work & \\
& Knowledge level & \\
& Initiative level & \\
& Level of ability and speed & \\
& Level of morale & \\
& Level of attendance and timeliness & \\
& & \\
\hline
\end{tabular}




\section{RESULTS}

From Table 1, the following can be inferred: a) The impact of organizational culture on students' performance (Table 1 shows that the significance value for the organizational culture variable was 0.007 . This value was less than $5 \%$. Therefore, the hypothesis that organizational culture had an impact on students' performance can be accepted. Regression analysis showed that organizational culture had a positive value. Therefore, the organizational culture variable had a positive impact on students' performance); b) The impact of motivation on students' performance (The significance value for the motivation variable was 0.066 . This value was less than $5 \%$. Therefore, the hypothesis that motivation had an impact on students' performance can be accepted. Regression analysis showed that motivation had a positive value. Therefore motivation variable had a positive impact on students' performance); c) The impact of self-leadership on students' performance (The significance value for the self-leadership variable was 0.007 . This value was less than 5\%. Therefore, the hypothesis that self-leadership had an impact on students' performance can be accepted. Regression analysis shows that self-leadership had a positive value. Therefore, the self-leadership variable had a positive impact on students' performance). Determination coefficient (R2) value can be seen in the Table 2.

Table 1. t-test on start-up performance

\begin{tabular}{lccc}
\hline \multicolumn{1}{c}{ Model } & $\mathrm{B}$ & Significance & Category \\
\hline (Constant) & 6.988 & 0.062 & \\
Organizational & 0.480 & 0.007 & H1 accepted \\
Culture (X1) & & & \\
Motivation (X2) & 0.161 & 0.066 & H2 accepted \\
$\begin{array}{l}\text { Self-leadership } \\
\text { (X3) }\end{array}$ & 0.415 & 0.007 & H3 accepted \\
\hline
\end{tabular}

Table 2. Determination coefficient test

\begin{tabular}{ll}
\hline Category & Value \\
\hline $\mathrm{R}$ & 0.700 \\
$\mathrm{R}$ Square & 0.490 \\
Adjusted R Square & 0,459 \\
\hline
\end{tabular}

Table 2 shows that organizational culture, motivation, and self-leadership examined had a relatively strong correlation to the dependent variable, which was students' performance since it had an R-value of 0.700 or $70 \%$. The adjusted $\mathrm{R}$ square shows that all three variables had an impact on students' performance with the magnitude of 0.459 or $45.9 \%$. The remaining of $54.1 \%$ was affected by other variables not explored in this research.

\section{Impact of Organizational Culture on Students' Performance}

The result of the t-test on the organizational culture variable had a significance value of 0.007 . This significance value was less than 0.05 . Therefore, the first hypothesis can be accepted, and organizational culture had an impact on Ciputra University Accountancy Study Program students' performance in their startup. The regression analysis result showed that the organizational culture variable had a positive impact on students' performance. From this positive impact, it can be concluded that the higher the organizational culture instilled in the students, the better the students' performance in their business.

Organizational culture, according to Schein, is a set of values, beliefs, and common norms that influences the business members' way of thinking and attitude towards their business. Therefore, businesses need to have values and norms to direct the business members' way of thinking and behavior (Agwu, 2014). Students try to be diligent in conducting their tasks and assignments and can efficiently work together in their start-ups. A strong culture can direct business members' behavior and influence members to work together in a synergistic manner (Merchant and Stede, 2016).

The result of this study is supported by Putra (2015), Hasan (2016), and Nazir and Zamir (2015), that stated that organizational culture influenced employees' performance. From this, it can be inferred that organizational culture has become one point to consider to improve students' performance in the start-up. 


\section{Impact of Motivation on Students' Performance}

The result of the t-test on the motivation variable had a significant value of 0.066 . This significance value was less than 0.1 . Therefore, the second hypothesis can be accepted, and motivation had an impact on Ciputra University Accountancy Study Program students' performance in their start-up. The regression analysis result showed that the motivation variable had a positive impact on students' performance. From this positive impact, it can be concluded that the higher the students' motivation, the better the students' performance in their business.

Motivation is something that sparks enthusiasm or incentive to work for business members to optimize their effort to achieve business (Santoso, 2017). Motivation itself includes accomplishments, affiliation, and power manifested in the student. It proves that the alignment of members' goals and the organization's goals can improve members' motivation to work (Merchant and Stede, 2016). Students' needs that are the foundation of motivation in running start-ups are parallel with the performance of Ciputra University Accountancy Study Program students in their start-ups. This result is supported by Omollo (2015) and Santoso (2017) that stated that motivation had an impact on employees' performance.

\section{Impact of Self-Leadership on Students' Performance}

The result of the t-test on the self-leadership variable had a significant value of 0.007 . This significance value was less than 0.05 . Therefore, the third hypothesis can be accepted, and self-leadership had an impact on Ciputra University Accountancy Study Program students' performance in their start-up. The regression analysis result showed that the self-leadership variable had a positive impact on students' performance. From this positive impact, it can be concluded that the higher students' self-leadership, the better the students' performance in their business.

Self-leadership is an individual's effort to influence themselves to exert more effort to be better in carrying out their individual tasks and responsibilities. (Priyantono, 2017). The result of this study is supported by Rachmawaty and Rohmah (2014) that stated that selfleadership had an impact on employees' performance.
From this, it can be inferred that self-leadership had become one point to consider to improve students' performance in the start-up.

\section{Managerial Implications}

This study implies that organizational culture needs to be developed in students' start-ups. Through the right organizational culture, students' start-ups performance can be improved. Entrepreneurship programs need to be designed systematically and accurately so that it is aligned with students' needs. The right entrepreneurship curriculum design can certainly increase students' motivation to start businesses. One important topic that needs to be continuously developed in the curriculum is leadership program, therefore, self-leadership can be improved for each student. The higher self-leadership, the higher the performance of the students' start-ups.

\section{CONCLUSIONS AND RECOMMENDATIONS}

\section{Conclusions}

Based on the analysis and discussion, it can be concluded that organizational culture, motivation, and self-leadership had an impact on Ciputra University Accountancy Study Program students' performance in their start-ups, and therefore, all hypotheses can be accepted.

\section{Recommendations}

The limitation experienced in this study was in terms of obtaining an honest response from the respondents. This limitation was caused by the majority of the respondents choosing the safest response, which is a neutral response. In addition, there are several suggestions for future studies, including adding other variables besides organizational culture, motivation, and self-leadership, because based on the research results, there were other factors that impact students' performance. Other factors can include work discipline, commitment, compensation, work environment, and others. Future studies can further explore the results of this study using a qualitative method such as interviewing respondents to obtain a clearer idea of the impact of organizational culture, motivation, and selfleadership on students' performance in start-ups. 


\section{REFERENCES}

Agwu MO. 2014. Organizational culture and employees performance in the national agency for food and drugs administration and control (NAFDAC) Nigeria. Global Journal of Management and Business Research: Administration and Management 14(2):1-11.

Akbar A. 2015. Pengaruh kompensasi, motivasi, disiplin kerja terhadap kinerja Karyawan CV. Cermara Production Surabaya. Jurnal Ilmu dan Riset Manajemen 4(10): 1-19.

Arianty N. 2014. Pengaruh budaya organisasi terhadap kinerja pegawai. Jurnal Manajemen dan Bisnis 14(2): 144-150.

Furtner M, Rauthmann J, Sachse P. 2015. Unique self-leadership: a bifactor model approach. Leadership 11(1): 105-125. https://doi. org/10.1177/1742715013511484.

Hasan S. 2016. Pengaruh budaya organisasi, kompensasi, motivasi, kepemimpinan terhadap kinerja karyawan Bandara Internasional Sultan Aji Muhammad Sulaiman. Jurnal Benefita 1(3): 134-145. https://doi.org/10.22216/jbe. v1i3.1076.

Jatilaksono RS, Indartono S. 2016. Pengaruh disiplin kerja dan budaya organisasi terhadap kinerja karyawan. Jurnal Manajemen Bisnis Indonesia 5(6): 588-603.

Masruroh, Sasriyah A. 2015. Analisis pengaruh goal orientation dan work motivation terhadap work role innovation dengan self-leadership sebagai mediator; studi pada perusahaan media (PT. Surya Citra Televisi). Binus Business Review 2: 258-267. https://doi.org/10.21512/bbr.v6i2.975.

Merchant K, Stede W. 2016. Sistem Pengendalian Manajemen. Jakarta: Salemba Empat.

Nazir N, Zamir S. 2015. Impact of organizational culture on employee's performance. Industrial Engineering Letters 5(9): 31-37.

Nisyak I. 2016. Pengaruh gaya kepemimpinan, motivasi, dan disiplin kerja terhadap kinerja karyawan. Jurnal Ilmu dan Riset Manajemen 5 (4): 1-22. https://doi.org/10.24912/je.v22i1.183.

Omollo PA. 2015. Effect of motivation on employee performance of commercial banks in Kenya:
A case study of Kenya Commercial Bank in Migori County. Journal of Human Resource Studies 5(2): 87-103. https://doi.org/10.5296/ ijhrs.v5i2.7504.

Priyantono P. 2017. Pengaruh self-leadership, selfefficacy, dan motivasi terhadap kinerja (studi pada independent business owner PT. AMWAY Indonesia di Semarang, Jawa Tengah). Manajemen Sumber Daya Manusia 6(2):131151.

Putra SW. 2015. Pengaruh komitmen organisasi, budaya organisasi, gaya kepemimpinan dan lingkungan terhadap kinerja karyawan pada industri kecil. Modernisasi 11(1): 62-77. https:// doi.org/10.21067/jem.v11i1.869.

Raf A, Desmiyawati, Wiguna M. 2014. Pengaruh gaya kepemimpinan, budaya organisasi, motivasi, dan lingkungan kerja terhadap kinerja akuntan pemerintah. Jom Fekon 1(2): 1-15.

Rahmawaty D, Rochmah T. 2014. Pengaruh kompetensi dan self-leadership terhadap kinerja petugas program pengendalian tuberkulosis (P2TB) Puskesmas di Kabupaten Jember. Jurnal Administrasi Kesehatan Indonesia 2(3): 169177.

Rahmi S. 2014. Kepemimpinan Transformasional dan Budaya Organisasi. Jakarta: Mitra Wacana Media.

Santoso AB. 2017. Pengaruh disiplin kerja, motivasi, dan komitmen organisasi terhadap kinerja karyawan. Jurnal Mandiri 1(2): 248-271. https:// doi.org/10.33753/mandiri.v1i2.21.

Sugiyono. 2015. Metode Penelitian dan Pengembangan. Bandung: Alfabeta.

Universitas Ciputra. 2015. Visi, Misi dan Nilai. Diambil kembali dari Universitas Ciputra: https://www. uc.ac.id/tentang-uc/visi-misi/

Vionita G, Sitepu M, Panjaitan F. 2017. Analisis pengaruhdisiplinkerja, loyalitas, dan pengalaman kerja terhadap kinerja kerja karyawan pada PT. Bank Tabungan Negara (Persero), TBK Cabang Pangkalpinang. Jurnal Ilmiah Progressif Manajemen Bisnis (JIPMB) 18 (2): 13-29.

Widarjono A. 2015. Analisis Multivariat Terapan. Yogyakarta: UPP STIM YKPN. 